\title{
Hemorrhage Increases Cytokine Expression in Lung Mononuclear Cells in Mice Involvement of Catecholamines in Nuclear Factor-кB Regulation and Cytokine Expression
}

Yves Le Tulzo, Robert Shenkar, Debra Kaneko, Pierre Moine, Giamila Fantuzzi, Charles A. Dinarello, and Edward Abraham

Division of Pulmonary Sciences and Critical Care Medicine, University of Colorado Health Sciences Center, Denver, Colorado 80262

\begin{abstract}
The expression of proinflammatory and immunoregulatory cytokines rapidly increases in the lungs after hemorrhage, and such alterations contribute to the frequent development of acute inflammatory lung injury in this setting. Blood loss also produces elevations in catecholamine concentrations in the pulmonary and systemic circulation. In the present experiments, we used $\alpha$ - and $\beta$-adrenergic receptor blockade to examine in vivo interactions between hemorrhage-induced adrenergic stimulation and pulmonary cytokine expression. Treatment of mice with the $\alpha$-adrenergic receptor antagonist phentolamine prevented not only the elevation in mRNA levels of IL- $1 \beta$, TNF- $\alpha$, and TGF- $\beta 1$, the increase in IL-1 $\beta$ protein, but also the activation of nuclear factor (NF)- $\kappa \mathrm{B}$ and cyclic AMP response element binding protein, which occurred in lung cells of untreated animals during the first hour after hemorrhage. In contrast, treatment before hemorrhage with the $\beta$-adrenergic receptor antagonist propranolol was associated with increases in mRNA levels for IL-1 $\beta$, TNF- $\alpha$, and TGF- $\beta 1$, which were greater than those present in untreated hemorrhaged mice, and did not prevent hemorrhage-associated increases in lung IL-1 $\beta$ protein. Treatment with propranolol prevented hemorrhageinduced phosphorylation of cyclic AMP response element binding protein, but increased hemorrhage-associated activation of NF- $\mathrm{kB}$. These results demonstrate that hemorrhage initially increases pulmonary cytokine expression through $\alpha$-but not $\beta$-adrenergic stimulation, and suggest that such $\alpha$-adrenergic-mediated effects occur through activation of the transcriptional regulatory factor NF-кB. $(J$. Clin. Invest. 1997. 99:1516-1524.) Key words: cytokines • adrenergic receptors $•$ lung $\bullet$ hemorrhage cyclic AMP response element binding protein
\end{abstract}

\section{Introduction}

Acute inflammatory lung injury, known clinically as the acute respiratory distress syndrome (1), is a life threatening disorder (mortality $>30-50 \%$ ) that occurs in as many as $50 \%$ of patients with severe trauma, burns, or hemorrhage $(2,3)$. Abnor-

Address correspondence to Edward Abraham, Division of Pulmonary Sciences and Critical Care Medicine, University of Colorado Health Sciences Center, Box C272, 4200 East Ninth Avenue, Denver, CO 80262. Phone: 303-315-7047; FAX: 303-315-5632.

Received for publication 2 August 1996 and accepted in revised form 23 January 1997.

J. Clin. Invest.

(C) The American Society for Clinical Investigation, Inc.

0021-9738/97/04/1516/09 \$2.00

Volume 99, Number 7, April 1997, 1516-1524 malities in immunoregulatory cytokine expression appear to be involved in the development of this inflammatory pulmonary process.

In murine models, mRNA levels of multiple cytokines, including IL- $1 \alpha$, IL- $1 \beta$, TNF- $\alpha$, and TGF- $\beta 1$, are increased in intraparenchymal pulmonary mononuclear cells and in alveolar macrophages, but not in peripheral blood mononuclear cells or splenocytes, within $1 \mathrm{~h}$ of blood loss (4). Similarly, in severely injured patients, increased levels of proinflammatory cytokines are found in the lungs, but not in the systemic circulation before the onset of acute lung injury (5-7). In experimental models, therapy with anticytokine agents, such as monoclonal antibodies to TGF- $\beta$, not only prevents posthemorrhage increases in proinflammatory cytokine expression, but also protects the treated animals from developing acute inflammatory lung injury (8).

In hemorrhagic shock, catecholamines are released in high concentrations into the pulmonary and systemic circulation $(9$, 10). Catecholamines have important regulatory functions on macrophages as well as on B and T cells (11-15). For example, in vitro experiments show that $\alpha$-adrenergic stimulation of macrophages leads to increased TNF- $\alpha$ expression $(16,17)$, while $\beta$-adrenergic stimulation, through an increase in cAMP, inhibits the production of cytokines such as TNF- $\alpha$, IL- $1 \beta$, and IL-6 (18-21).

In previous studies $(22,23)$, we found that hemorrhage was associated with a rapid activation of the nuclear transcriptional regulatory factors nuclear factor $(\mathrm{NF})^{1}-\kappa \mathrm{B}$ and cyclic AMP response element binding protein (CREB) in pulmonary mononuclear cell populations. Because binding sites for $\mathrm{NF}-\kappa \mathrm{B}$ and CREB are present in the promoter regions of cytokine genes, such as IL- $1 \beta, \mathrm{TNF}-\alpha$, and TGF- $\beta$, for which transcription is enhanced after hemorrhage (24-29), we investigated the role of hemorrhage-induced adrenergic stimulation on immunoregulatory cytokine expression and transcriptional regulatory factor activation in lung cells. The present experiments demonstrate that the initial hemorrhage-induced increase in pulmonary cytokine expression as well as activation of NF- $\mathrm{B}$ is prevented by $\alpha$-adrenergic blockade. These studies suggest that activation of NF-кB through $\alpha$-adrenergic stimulation is a mechanism by which blood loss produces increased immunoregulatory cytokine expression in the lungs.

\section{Methods}

Animals

Male BALB/c mice, 8 to 12 wk of age, were obtained from Harlan Sprague-Dawley Co. (Indianapolis, IN) and The Jackson Laboratories (Bar Harbor, ME). The mice were kept on a 12-h light/dark cycle

1. Abbreviations used in this paper: $\mathrm{CREB}$, cyclic AMP response-element binding protein; EMSA, electrophoresis mobility shift assay; $\mathrm{NF}$, nuclear factor; PKC, protein kinase $\mathrm{C}$. 
with free access to food and water. All experiments were performed in accordance with institutional review board-approved protocols and followed National Institutes of Health (NIH) guidelines for the use of laboratory animals.

\section{Hemorrhage model}

The murine hemorrhage model used in these experiments was developed in our laboratory and reported previously $(4,30-33)$. With this model, $30 \%$ of the calculated blood volume $(\sim 0.55 \mathrm{ml}$ for a $20 \mathrm{-g}$ mouse) is withdrawn from a methoxyflurane-anesthetized mouse (Pittman-Moore Inc., Mundelein, IL) over a 60-s period by cardiac puncture and collected in a heparinized syringe (5 $\mathrm{U}$ heparin). The period of methoxyflurane anesthesia is $<2 \mathrm{~min}$ in all cases. The mortality rate with this hemorrhage protocol is $\sim 12 \%$, with all deaths occurring within the 1 -h posthemorrhage period.

Previous studies in mice $(32,33)$ subjected to anesthesia and cardiac puncture without blood withdrawal have documented no changes in mitogen-induced lymphocyte proliferation, interleukin-2 receptor expression, phenotypic characteristics (CD3, CD4, CD8, $\mathrm{B} 220, \mu$, or Ly-1 expression) of B or T lymphocytes, cytokine (interleukin- $1,-2,-3,-4,-5,-10$, interferon- $\gamma$, TGF- $\beta 1$, or TNF- $\alpha$ ) expression, nor splenic or pulmonary B cell clonal precursor frequencies. In addition, hemothorax, hemopericardium, and lung or cardiac contusion do not occur in surviving mice with this method of hemorrhage (32-34).

\section{Interventions}

$\alpha$-Adrenergic blockade. Mice were treated with phentolamine (Sigma Chemical Co., St. Louis, MO) at $10 \mathrm{mg} / \mathrm{kg}$ in $200 \mu \mathrm{l}$ normal saline i.p. $30 \mathrm{~min}$ before hemorrhage. This dose has previously been shown to produce $\alpha$-adrenergic blockade in mice, as determined by its effects on $\alpha$-adrenergic-induced alterations in intestinal transit (35), insulin secretion (36), and release of endogenous catecholamines (37).

$\beta$-Adrenergic blockade. Mice were treated with propranolol (Sigma Chemical Co.) at $3 \mathrm{mg} / \mathrm{kg}$ in $200 \mu \mathrm{l}$ normal saline i.p. $30 \mathrm{~min}$ before hemorrhage. This dose of propranolol has previously been shown to produce $\beta$-adrenergic blockade in mice as determined by its effects on basal heart rate (38), LPS-induced TNF- $\alpha$ release (39), and stress-induced locomotor activity (40).

Control groups. Control, hemorrhaged mice received $200 \mu$ normal saline i.p. $30 \mathrm{~min}$ before blood loss to assure that any alterations seen in treatment groups were due to the drug and not the volume of saline in which the drug was delivered. Unmanipulated, unhemorrhaged mice, as well as mice treated with phentolamine or propranolol, but not subjected to hemorrhage, also served as control groups.

\section{Isolation of intraparenchymal pulmonary mononuclear cells}

Intraparenchymal pulmonary mononuclear cells were isolated by collagenase digestion and Percoll gradient purification, using techniques previously described by our laboratory (41). Briefly, mice were anesthetized with methoxyflurane and killed by cervical dislocation $1 \mathrm{~h}$ after hemorrhage for experiments requiring mRNA isolation for PCR, or $15 \mathrm{~min}$ after hemorrhage for experiments in which nuclear proteins were purified for electrophoresis mobility shift assay (EMSA). The chest was opened and the lung vascular bed was flushed by injecting $3-5 \mathrm{ml}$ of chilled $\left(4^{\circ} \mathrm{C}\right) \mathrm{PBS}$ into the right ventricle. Lungs were then excised, avoiding the paratracheal lymph nodes, and washed twice in RPMI 1640 medium containing $25 \mathrm{mM}$ Hepes, penicillin/streptomycin/L-glutamine. The lungs from one mouse (for mRNA isolation and semiquantitative PCR), or pooled from 12 mice (for EMSA) were minced finely, and the tissue pieces were placed in RPMI 1640 medium containing $5 \%$ fetal calf serum, $20 \mathrm{U} / \mathrm{ml}$ collagenase, and $1 \mu \mathrm{g} /$ $\mathrm{ml}$ DNase (Sigma Chemical Co.). After incubation for $60 \mathrm{~min}$ at $37^{\circ} \mathrm{C}$, any remaining intact tissue was disrupted by passage through a $21-$ gauge needle. Tissue fragments and dead cells were removed by rapid filtration through a glass wool column, and cells were collected by centrifugation. The cell pellet was suspended in $4 \mathrm{ml}$ of $80 \%$ Percoll (Pharmacia Fine Chemicals, Uppsala, Sweden) upon which $4 \mathrm{ml}$ of $40 \%$ Percoll was layered. After centrifugation at $600 \mathrm{~g}$ for $20 \mathrm{~min}$ at $15^{\circ} \mathrm{C}$, the cells at the interface were collected, washed in RPMI 1640 medium, and counted. Viability as determined by trypan blue exclusion was consistently $>98 \%$.

\section{Semiquantitative polymerase chain reaction}

The basic procedure for semiquantitative PCR was developed in our laboratory and described previously $(4,8,30,42)$. Groups of six mice, with PCR results obtained from individual mice, were used for each experimental condition. After isolated cellular populations had been lysed in $4 \mathrm{M}$ guanidium thiocyanate $/ 25 \mathrm{mM}$ sodium citrate $/ 0.5 \%$ sarcosyl/0.1 M 2-mercaptoethanol, mRNA was phenol-extracted according to the method of Chomczynski and Sacchi (43). cDNA was synthesized from the mRNA of 100,000 intraparenchymal mononuclear cells, using Moloney murine leukemia virus reverse transcriptase (Gibco Laboratories, Grand Island, NY) and random hexamer oligonucleotides (Pharmacia Fine Chemicals) (39). After a 4-min, $95^{\circ} \mathrm{C} \mathrm{de-}$ naturation step, between 26 and 35 cycles of PCR were conducted ( $1 \mathrm{~min}, 95^{\circ} \mathrm{C}$ denaturation; $1 \mathrm{~min}, 60^{\circ} \mathrm{C}$ annealing; and $1 \mathrm{~min}, 72^{\circ} \mathrm{C} \mathrm{ex}$ tension) on cDNA from 5,000 cells (1,000 cells for IL-1 $\beta)$. All cDNA samples for every treatment group were mixed with aliquots from the same PCR master mix (44) using appropriate cytokine MIMICs (Clontech, Palo Alto, CA) and the housekeeping gene HPRT as internal controls for standardization of PCR products (45). Cytokine primers (Clontech) were used at $0.4 \mu \mathrm{M}$. To detect amplified cDNA, the PCR product was analyzed by agarose gel electrophoresis. The number of PCR cycles was selected for the cytokine product so that the ethidium bromide-stained amplified DNA products were between barely detectable and below saturation levels. The gel was analyzed via computer integration (UVP Inc., San Gabriel, CA). Results for each cytokine were normalized to those for the appropriate MIMIC.

\section{Measurement of plasma epinephrine levels}

Plasma was collected from unhemorrhaged control mice, from mice subjected to hemorrhage $1 \mathrm{~h}$ previously, and from mice hemorrhaged $1 \mathrm{~h}$ previously but treated with either phentolamine or propranolol before hemorrhage. These plasma specimens were stored at $-80^{\circ} \mathrm{C}$ until assayed. Epinephrine levels were measured in the plasma specimens using a radioenzymatic assay, as originally described by Passon and Peuler (46) and others (47).

\section{$I L-1 \beta$ and TNF- $\alpha$ ELISA}

After the lung vascular bed had been flushed by injecting $5 \mathrm{ml}$ of chilled $\left(4^{\circ} \mathrm{C}\right)$ PBS into the right ventricle, lung homogenates were prepared by snap freezing isolated lungs in liquid nitrogen. The lungs were then homogenized (30-s pulse on ice) in lysis buffer containing $1 \%$ Nonidet P-40, $50 \mathrm{mM}$ Hepes, $500 \mathrm{mM} \mathrm{NaCl}$, and $1 \mathrm{mg} / \mathrm{ml}$ leupeptin (Sigma Chemical Co.). The homogenates were centrifuged at $2,500 \mathrm{rpm}$ at $4^{\circ} \mathrm{C}$ for $10 \mathrm{~min}$, and the supernatants were collected. Immunoreactive IL- $1 \beta$ and TNF- $\alpha$ were quantitated using commercially available ELISA kits specific for IL- $1 \beta$ or TNF- $\alpha$ (Endogen, Inc., Boston, MA) as previously described (48). With these assays, the threshold of sensitivity for IL- $1 \beta$ is $3 \mathrm{pg} / \mathrm{ml}$ and for TNF- $\alpha$ is $10 \mathrm{pg} / \mathrm{ml}$.

\section{Preparation of nuclear extract}

The basic procedure for preparation of nuclear extracts was previously described by our laboratory $(22,23)$. After purification, the intrapulmonary mononuclear cells, pooled from 12 mice, were washed with PBS, and then the nuclear proteins were isolated by the method of Qian et al. (49). Briefly, 2-3 $\times 10^{7}$ cells were resuspended in buffer A (50), incubated on ice for $15 \mathrm{~min}$, and homogenized by 15 passages through a 25-gauge needle. After centrifugation for $6 \mathrm{~min}$ at $600 \mathrm{~g}$ at $4^{\circ} \mathrm{C}$, the nuclear pellet was resuspended in buffer $\mathrm{C}(50)$ and incubated on ice for $15 \mathrm{~min}$. The nuclear extract was centrifuged for 10 $\min$ at $12,000 \mathrm{~g}$ and $4^{\circ} \mathrm{C}$. The supernatant was collected, divided into aliquots, and stored at $-70^{\circ} \mathrm{C}$. Protein concentration was determined by the Bradford dye binding procedure (Bio-Rad Protein Assay; BioRad Laboratories, Hercules, CA), standardized with bovine serum albumin. 


\section{Electrophoresis mobility shift assay}

The кB DNA of the immunoglobulin gene (51) and the CREB-conserved element (52) were used for EMSA. Synthetic double stranded oligonucleotides of the following sequences (with enhancer motif underlined) were fill-in labeled with $\alpha{ }^{32} \mathrm{P}$-dATP using Sequenase version 2.0 T7 DNA polymerase (United States Biochemical, Cleveland, $\mathrm{OH})$

кB: 5' TCGACGAGCTCGGGACTTTCCGAGC

3' GCTCGAGCCCTGAAAGGCTCGAGCT

CRE: 5' TCGACGAGCTCTGACGTCAGAGC

3' GCTCGAGACTGCAGTCTCGAGCT

The DNA binding reaction was conducted at room temperature for $20 \mathrm{~min}$ in a volume of $20 \mu \mathrm{l}$. The reaction mixture contained 1.5$2.5 \mathrm{mg}$ nuclear extract, $10 \mathrm{mM}$ Tris. $\mathrm{Cl}, \mathrm{pH} 7.5,50 \mathrm{mM} \mathrm{NaCl}, 0.5 \mathrm{mM}$ EDTA, $0.5 \mathrm{mM}$ dithiothreitol, $1 \mathrm{mM} \mathrm{MgCl}_{2}, 4 \%$ glycerol, poly(dI$\mathrm{dC})$-poly $(\mathrm{dI}-\mathrm{dC})$ at $0.08 \mu \mathrm{g} / \mu \mathrm{g}$ nuclear extract, and ${ }^{32} \mathrm{P}$-labeled double stranded nucleotides at $0.7 \mathrm{fmol} / \mu \mathrm{g}$ nuclear extract. For supershift experiments, antibodies to either the p50 subunit of NF-kB $(5 \mu \mathrm{l})$ (Santa Cruz Biotechnology, Santa Cruz, CA) or phospho-CREB (1 $\mu 1)$ (Upstate Biotechnology Inc., Lake Placid, NY) were added to the reaction mixture just before the 20 -min incubation. After incubation, the samples were loaded onto a $4 \%$ polyacrylamide gel (acrylamide/ bisacrylamide $80: 1,2.5 \%$ glycerol in $0.5 \times$ Tris-borate-EDTA), and the gel subjected to electrophoresis at $10 \mathrm{~V} / \mathrm{cm}$. The gel was then dried and analyzed by autoradiography.

\section{Statistical analysis}

Because of inherent variability between groups of mice, for each experimental condition, the entire group of animals was prepared and studied at the same time. For each experimental condition, mice in all groups (i.e., control, hemorrhage, propranolol or phentolamine treated, and propranolol or phentolamine treated before hemorrhage) had the same birthdate and had been housed together. No pooling of data from groups of mice from separate experiments or with different birthdates was performed. Separate groups of mice were used for measuring plasma epinephrine levels, semiquantitative PCR, electrophoresis mobility shift assays, and determination of lung IL- $1 \beta$ and TNF- $\alpha$ protein. For semiquantitative PCR, cells were obtained individually from each animal and analyzed individually before calculating group data. Data are presented as mean \pm SEM for each experimental group. One way ANOVA and the Student-Newman-Keuls test were used for comparisons between data groups. $P<$ 0.05 was considered significant.

\section{Results}

Effects of hemorrhage with or without $\alpha$ - or $\beta$-adrenergic blockade on plasma epinephrine levels. Plasma epinephrine levels increased from $855 \pm 325 \mathrm{pg} / \mathrm{ml}$ in control mice to $1,433 \pm 400$ $\mathrm{pg} / \mathrm{ml} 1 \mathrm{~h}$ after hemorrhage $(P<0.05$ vs. control $)$. In mice pretreated with propranolol, plasma epinephrine levels $1 \mathrm{~h}$ after hemorrhage were $1,716 \pm 558 \mathrm{pg} / \mathrm{ml}$, and in mice pretreated with phentolamine, plasma epinephrine levels were $2,116 \pm 208$ $\mathrm{pg} / \mathrm{ml} 1 \mathrm{~h}$ after blood loss.

Effect of $\alpha$-blockade on cytokine $m R N A$ levels among intraparenchymal pulmonary mononuclear cells. In hemorrhaged mice, the levels of mRNA for IL- $1 \beta, \mathrm{TNF}-\alpha$, and TGF- $\beta 1$ were increased in lung cells isolated $1 \mathrm{~h}$ after blood loss. In contrast, treatment with the $\alpha$-adrenergic receptor antagonist phentolamine prevented the hemorrhage-induced elevation in cytokine mRNA levels (Figs. 1 and 2). In the hemorrhaged mice treated with phentolamine, the amounts of mRNA for IL-1 $\beta$, TNF- $\alpha$, and TGF- $\beta 1$ after blood loss were similar to those seen in unhemorrhaged animals. Treatment of unhemorrhaged mice with phentolamine did not alter mRNA levels for IL-1 $\beta$, TNF- $\alpha$, or TGF- $\beta 1$ among intraparenchymal pulmonary mono-
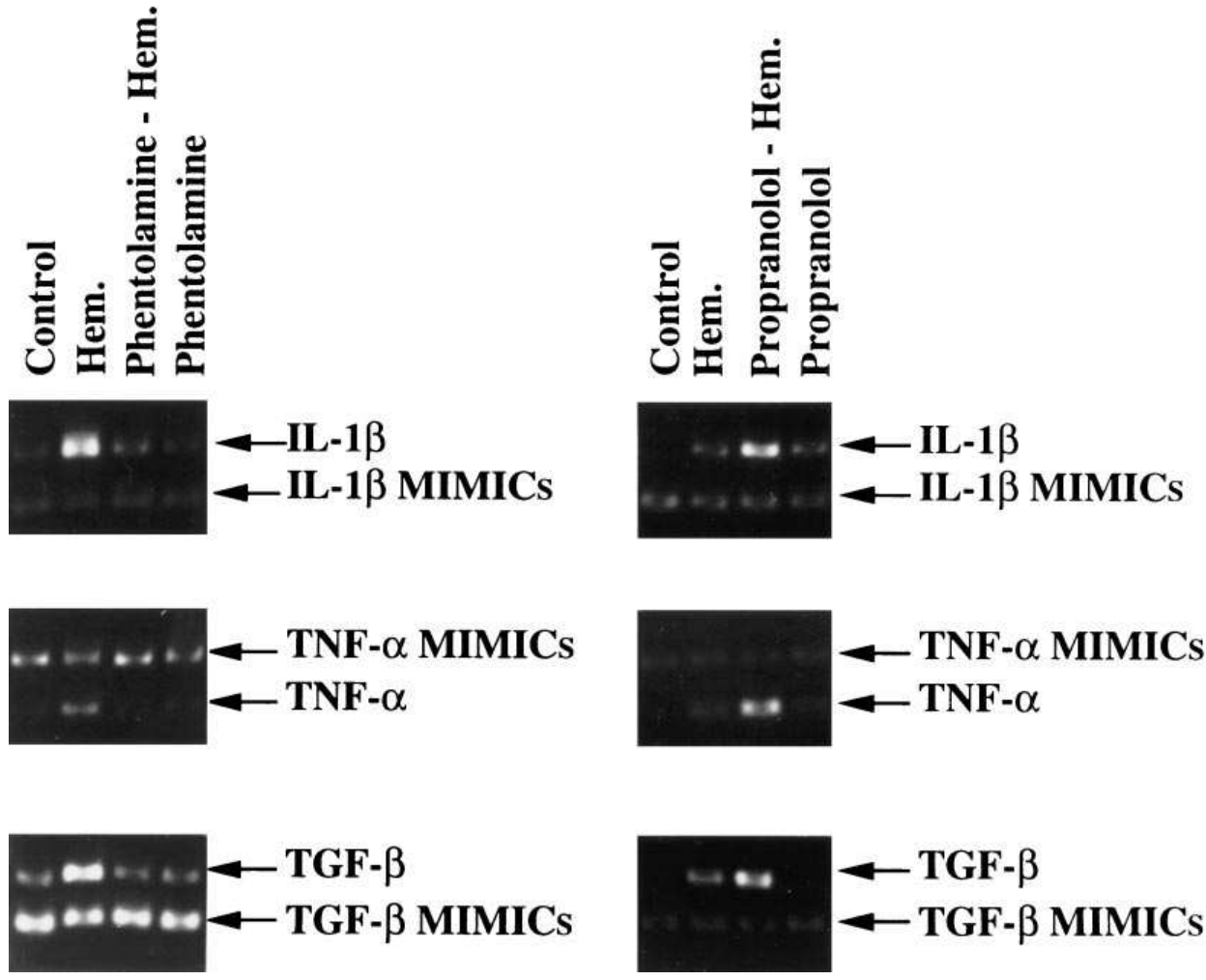

Figure 1. mRNA levels for intraparenchymal pulmonary mononuclear cells isolated from unmanipulated mice (Control), and from mice killed $1 \mathrm{~h}$ after $30 \%$ blood volume hemorrhage (Hem.), treated with the $\alpha$-adrenergic receptor antagonist, phentolamine, $30 \mathrm{~min}$ before hemorrhage (Phentolamine-Hem.), treated with phentolamine but without hemorrhage (Phentolamine), treated with the $\beta$-adrenergic receptor antagonist, propranolol, $30 \mathrm{~min}$ before hemorrhage (PropranololHem.), or treated with propranolol but without hemorrhage (Propran$o l o l)$. Results from two representative experiments (i.e., with either phentolamine or propranolol treatment groups) are shown. 

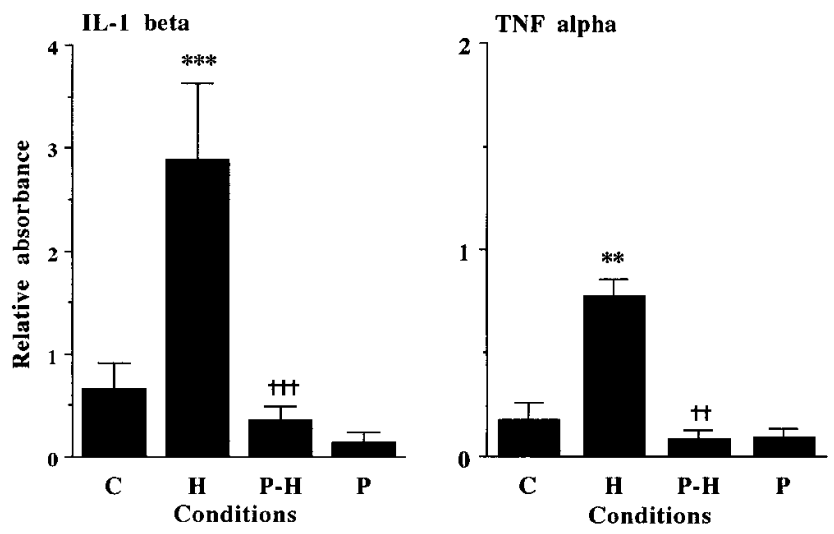

nuclear cells compared with untreated, unhemorrhaged mice (Fig. 2).

Effect of $\beta$ blockade on cytokine $m R N A$ levels among intraparenchymal pulmonary mononuclear cells. Treatment of mice with the $\beta$-adrenergic receptor antagonist propranolol before blood loss did not attenuate the hemorrhage-associated increases in the mRNA levels of IL- $1 \beta$, TNF- $\alpha$, and TGF- $\beta 1$ $(P<0.01, P<0.001$, and $P<0.01$, respectively, compared with unhemorrhaged animals) among intraparenchymal pulmonary mononuclear cells (Fig. 3). In fact, in hemorrhaged mice treated with propranolol, mRNA levels for IL-1 $\beta$ and TNF- $\alpha$ were significantly higher $(P<0.01, P<0.05$, respectively) than those present in untreated hemorrhaged mice (Fig. 3). A similar trend towards a further increase in mRNA levels for TGF- $\beta 1$ above those in untreated hemorrhaged mice was found in propranolol-treated hemorrhaged mice. However, this difference did not reach statistical significance.

As was the case with phentolamine, treatment of unhemor-

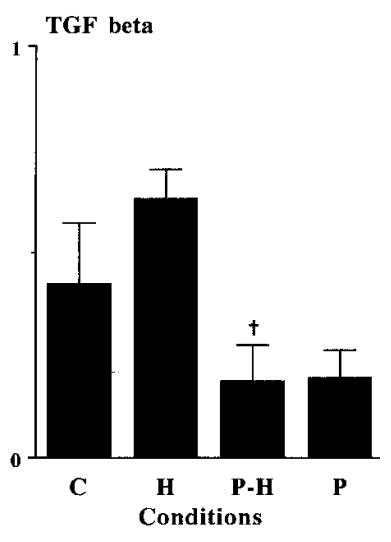

Figure 2. Effects of $\alpha$ blockade on hemorrhage-induced alterations of cytokine mRNA expression. Cytokine mRNA levels among intraparenchymal pulmonary mononuclear cells isolated from control mice $(C)$, mice killed $1 \mathrm{~h}$ after $30 \%$ blood volume hemorrhage $(H)$, treated with the $\alpha$-adrenergic receptor antagonist, phentolamine, 30 min before hemorrhage $(P-H)$, or treated with phentolamine but without hemorrhage $(P)$ are shown $(n=$ 6 in each group). Results are normalized to those for the appropriate cytokine MIMIC and shown as mean relative absorbance \pm SEM $(* * * P<0.001, * * P<0.01$ vs. control; ${ }^{\dagger \dagger \dagger} P<0.001,{ }^{\dagger \dagger} P<0.01,{ }^{\dagger} P<$ 0.05 vs. hemorrhaged untreated). rhaged mice with propranolol did not significantly change mRNA levels in lung cells for IL- $1 \beta, \mathrm{TNF}-\alpha$, and TGF- $\beta 1$ compared with untreated, unhemorrhaged mice (Fig. 3).

Effects of $\alpha$ - and $\beta$-adrenergic blockade on lung $I L-1 \beta$ and TNF- $\alpha$ levels. By $1 \mathrm{~h}$ after hemorrhage, IL-1 $\beta$ protein in the lungs had increased by more than twofold $(P<0.001$ compared with levels present in control, unhemorrhaged mice) (Fig. 4). Treatment with the $\alpha$-adrenergic receptor antagonist phentolamine before blood loss prevented the hemorrhageassociated increase in lung IL-1 $\beta$. In contrast, lung IL- $1 \beta$ protein levels continued to be significantly elevated in hemorrhaged mice pretreated with the $\beta$-adrenergic receptor antagonist propranolol $(P<0.05$ compared with levels in control unmanipulated or propranolol-treated, unhemorrhaged animals). Treatment of unhemorrhaged mice with either propranolol or phentolamine did not affect IL-1 $\beta$ levels in the lungs. In contrast to IL-1 $\beta$, for which immunoreactive protein was present in lung homogenates from control and hemorrhaged mice, no
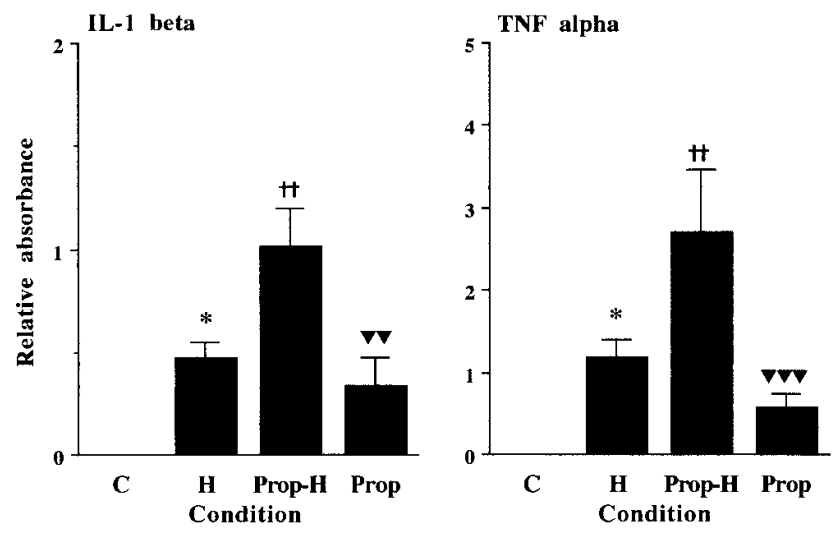

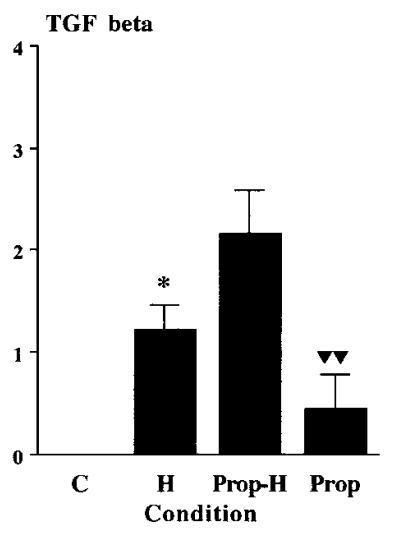

Figure 3. Effects of $\beta$ blockade on hemorrhage-induced alterations of cytokine mRNA expression. Cytokine mRNA levels among intraparenchymal pulmonary mononuclear cells isolated from control mice $(C)$, or from mice killed $1 \mathrm{~h}$ after $30 \%$ blood volume hemorrhage $(H)$, treated with the $\beta$-adrenergic receptor antagonist, propranolol, 30 min before hemorrhage (Prop- $H$ ), or treated with propranolol but without hemorrhage (Prop) are shown ( $n=6$ in each group). Results are normalized to those for the appropriate cytokine MIMIC and shown as mean relative absorbance \pm SEM. $(* P<0.05$ vs. control; ${ }^{\dagger \dagger} P<0.01$ vs. hemorrhaged untreated; $\boldsymbol{\nabla} \nabla \boldsymbol{\nabla} P<0.001, \boldsymbol{\nabla} \nabla P<$ 0.01 vs. hemorrhage pretreated with propranolol). 


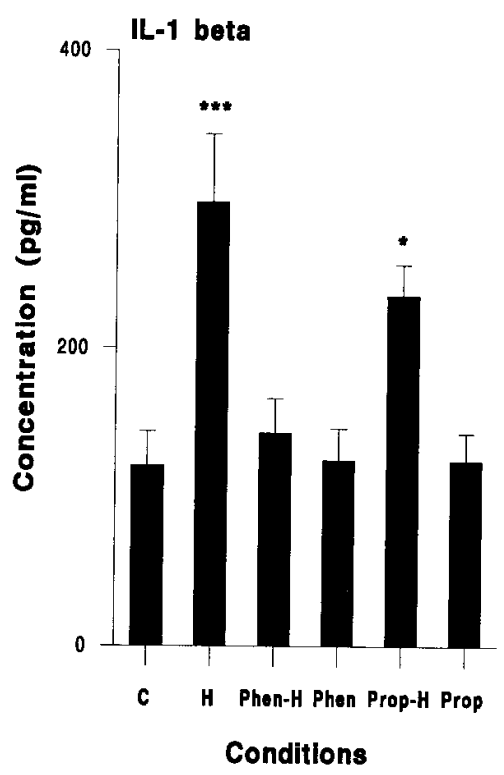

(Prop-H), or treated with propranolol but without hemorrhage (Prop) are shown ( $n=5-6$ in each group). Results are shown as mean $\mathrm{pg} / \mathrm{ml} \pm$ SEM $(* * * P<0.001, * P<0.05$ vs. control).

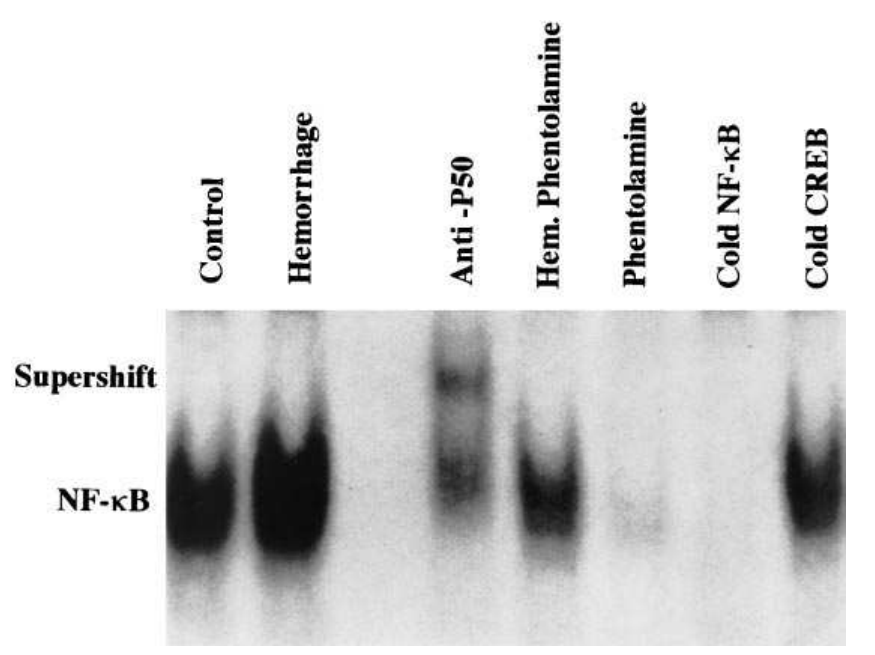

Figure 5. Effects of $\alpha$-adrenergic blockade on NF-кB activation in lung cells. Electrophoresis mobility shift assay analysis for NF-кB activity in intraparenchymal pulmonary mononuclear cells isolated from control mice (Control, Cold NF- $\mathrm{B}$, Cold CREB), mice killed 15 min after $30 \%$ blood volume hemorrhage (Hemorrhage, Anti-P50), treated with the $\alpha$-adrenergic receptor antagonist, phentolamine, 30 min before hemorrhage (Hem. Phentolamine), or treated with phentolamine but without hemorrhage (Phentolamine) is shown. 12 mice were used in each group. In each case, $2 \mu \mathrm{g}$ of nuclear extract were incubated with ${ }^{32} \mathrm{P}$-labeled $\kappa \mathrm{B}$ oligonucleotide. The specificity of $\mathrm{NF}-\mathrm{\kappa B}$ binding to the $\mathrm{\kappa B}$ sequence was confirmed by incubation of nuclear extracts with antibodies to the p50 subunit of NF- $\mathrm{kB}$ before EMSA (Anti-P50) and by adding a 500-fold excess of unlabeled $\kappa \mathrm{B}$ (Cold $N F-\kappa B$ ) or unlabeled heterologous CRE oligonucleotide (Cold $C R E B)$. Constitutive and hemorrhage-induced NF- $\mathrm{KB}$ activation (Control, Hemorrhage) are reduced by phentolamine (Hem. Phentolamine, Phentolamine). One representative experiment is shown, three additional experiments with separate sets of animals gave comparable results.
TNF- $\alpha$ protein was detectable either in the lungs of control mice or mice hemorrhaged $1 \mathrm{~h}$ previously.

Effects of $\alpha$-adrenergic blockade on hemorrhage-induced activation of $N F-\kappa B$ and $C R E B$. NF- $\mathrm{BB}$ was constitutively activated within nuclear extracts of intraparenchymal pulmonary mononuclear cells from unmanipulated mice as shown by retardation of the migration of labeled $\kappa \mathrm{B}$ oligonucleotide (Fig. 5 , control). As previously found (22), activation of NF-кB was increased in lung cells obtained 15 min after hemorrhage (Fig. 5, Hemorrhage).

The hemorrhage-induced activation of NF-кB in lung cells was reduced by $\alpha$-adrenergic blockade with phentolamine. In hemorrhaged mice pretreated with phentolamine, the level of NF- $\kappa \mathrm{B}$ activation was markedly lower than that observed in untreated, hemorrhaged mice, and was even lower than that present in unmanipulated mice (Fig. 5, compare Hem. Phentolamine and Hemorrhage, and Hem. Phentolamine and Control). Of note, treatment of unhemorrhaged mice with phentolamine also reduced basal activation of NF-кB (Fig. 5, Cold $C R E B)$.

Phosphorylation of CREB on serine residue 133 is responsible for its transcriptional activity (53). To determine if $\alpha$-adrenergic blockade alters activation of CREB in lung mononuclear cells, antiphospho-CREB antisera was added to the incubation

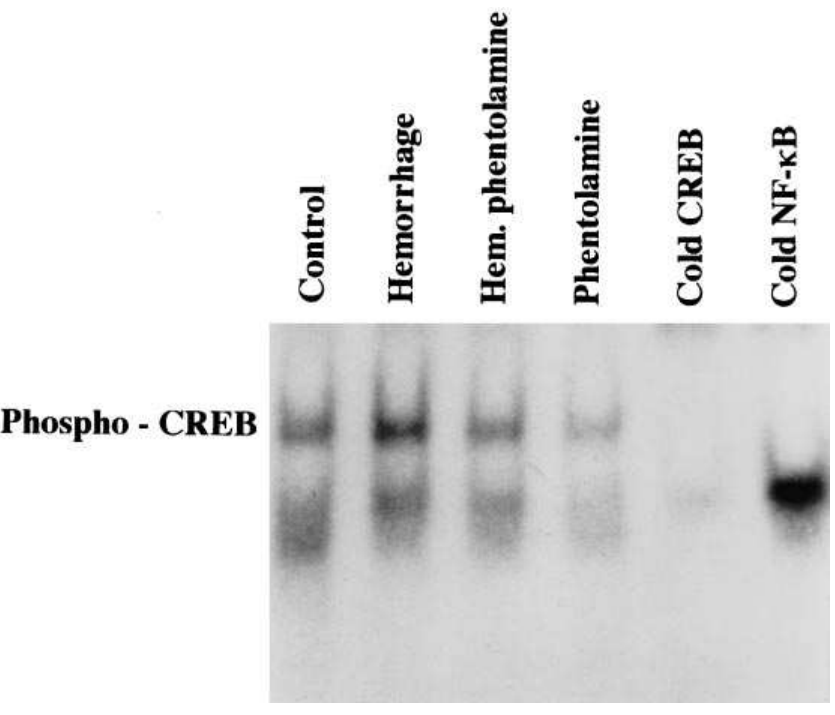

Figure 6. Effects of $\alpha$-adrenergic blockade on CREB activation in lung cells. Electrophoresis mobility shift assay analysis for CREB activation in intraparenchymal pulmonary mononuclear cells isolated from control mice (Control, Cold CREB, Cold NF- $\kappa B$ ), mice killed 15 min after $30 \%$ blood volume hemorrhage (Hemorrhage), treated with the $\alpha$-adrenergic receptor antagonist, phentolamine, $30 \mathrm{~min}$ before hemorrhage (Hem. phentolamine), or treated with phentolamine but without hemorrhage (Phentolamine) is shown. 12 mice were used in each group. In each case, $2.16 \mu \mathrm{g}$ of nuclear extract were incubated with ${ }^{32} \mathrm{P}$-labeled $\kappa \mathrm{B}$ oligonucleotide. The specificity of CREB binding to the CRE sequence was confirmed by the addition of a 500 -fold excess of unlabeled CRE (Cold CREB) or unlabeled heterologous $\mathrm{\kappa B}$ oligonucleotide (Cold $N F-\kappa B$ ). Pretreatment with phentolamine reduced constitutive (compare Control and Phentolamine) and hemorrhage-induced CREB activation (compare Hemorrhage and Hem. phentolamine). One representative experiment is shown, one additional experiment with another set of animals gave comparable results. 
reaction before EMSA, and the intensity of the supershifted DNA-protein band (i.e., phosphorylated CREB) was examined.

The nuclear factor CREB was constitutively phosphorylated in small amounts within nuclear extracts from intraparenchymal pulmonary mononuclear cells of unmanipulated mice (Fig. 6, Control). Consistent with previous results (54), hemorrhage resulted in a rapid (i.e, within $15 \mathrm{~min}$ ) increase in the phosphorylated CREB, as shown by the increased intensity of the supershifted band (Fig. 6, Hemorrhage).

Pretreatment of unhemorrhaged mice with the $\alpha$-adrenergic receptor antagonist phentolamine decreased constitutive activation of CREB (Fig. 6, Phentolamine). In phentolaminetreated mice, $\alpha$-adrenergic blockade reduced hemorrhageinduced increases in CREB activation (Fig. 6, Hem. phentolamine). In hemorrhaged mice treated with phentolamine, the amount of phospho-CREB was lower than that observed in untreated, hemorrhaged mice (Fig. 6, compare Hem. phentolamine and Hemorrhage), and was similar to that found in unmanipulated animals (Fig. 6, Control).

Effects of $\beta$-adrenergic blockade on hemorrhage-induced activation of $N F-\kappa B$ and $C R E B$. The level of activation of $N F-\kappa B$ in hemorrhaged mice pretreated with the $\beta$-adrenergic receptor antagonist propranolol was higher than that observed in

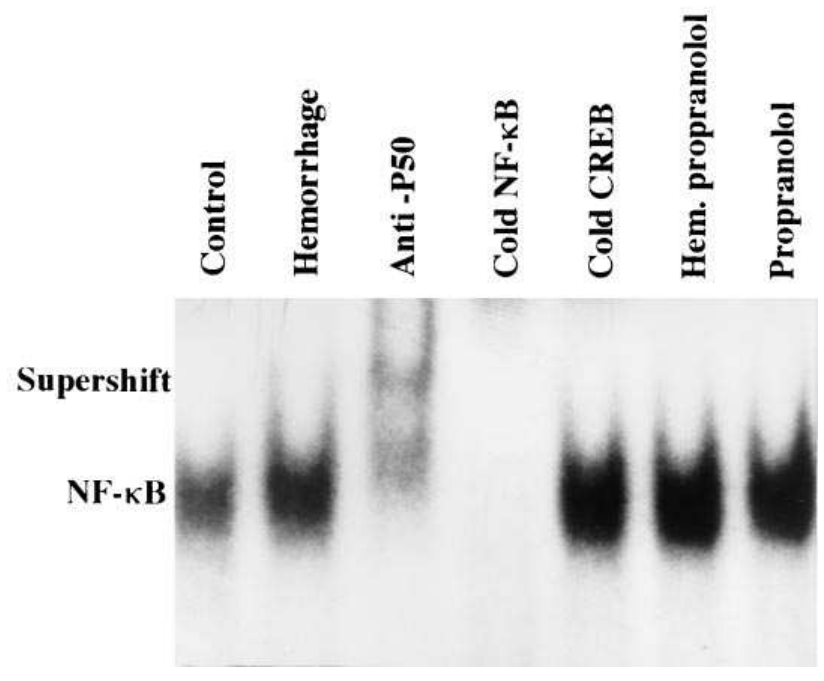

Figure 7. Effects of $\beta$-adrenergic blockade on NF-кB activation in lung cells. Electrophoresis mobility shift assay analysis for NF-кB activity in intraparenchymal pulmonary mononuclear cells isolated from control mice (Control), mice killed $15 \mathrm{~min}$ after $30 \%$ blood volume hemorrhage (Hemorrhage), treated with the $\beta$-adrenergic receptor antagonist, propranolol, $30 \mathrm{~min}$ before hemorrhage (Hem. propranolol), or treated with propranolol but without hemorrhage (Propranolol) is shown. 12 mice were used in each group. In each case, $2.16 \mu \mathrm{g}$ of nuclear extract were incubated with ${ }^{32} \mathrm{P}$-labeled $\kappa \mathrm{B}$ oligonucleotide. The specificity of NF- $\mathrm{KB}$ binding to the $\mathrm{\kappa B}$ sequence was confirmed by incubation of nuclear extracts with antibodies to the p50 subunit of NF-kB before EMSA (Anti-P50) or by the addition a 500-fold excess of unlabeled $\kappa \mathrm{B}($ Cold $N F-\kappa B)$ or unlabeled heterologous CRE oligonucleotide (Cold CREB). Constitutive and hemorrhage-induced NF- $\mathrm{BB}$ activation are increased by propranolol (compare Control and Propranolol, and Hemorrhage and Hem. propranolol) when compared with untreated mice. One representative experiment is shown, one additional experiment with another set of animals gave comparable results.

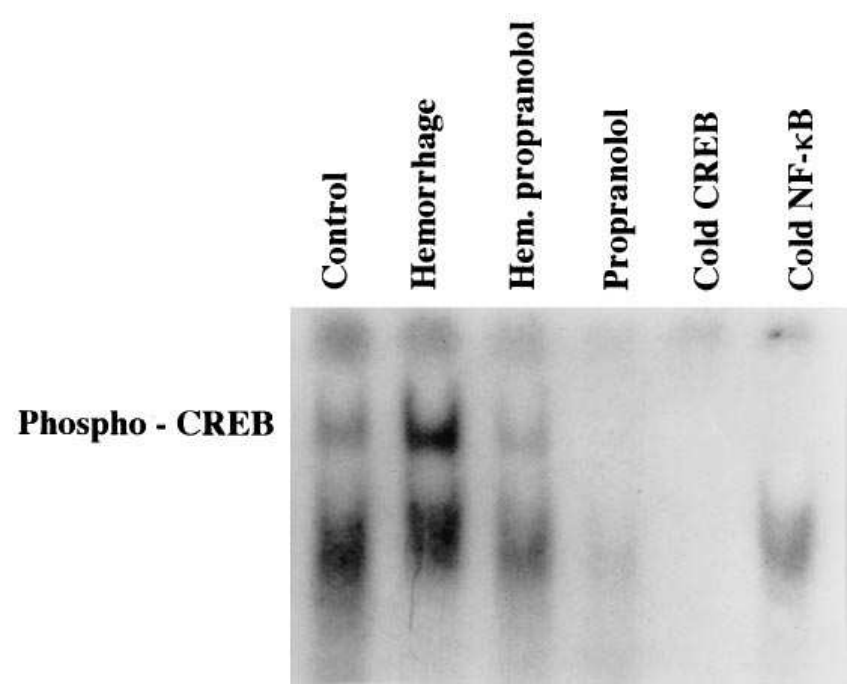

Figure 8. Effects of $\beta$-adrenergic blockade on CREB activation in lung cells. Electrophoresis mobility shift assay analysis for CREB activation in intraparenchymal pulmonary mononuclear cells isolated from control mice (Control), mice killed 15 min after $30 \%$ blood volume hemorrhage (Hemorrhage), treated with the $\beta$-adrenergic receptor antagonist, propranolol, $30 \mathrm{~min}$ before hemorrhage (Hem. pro-

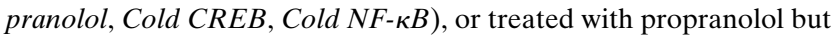
without hemorrhage (Propranolol) is shown. 12 mice were used in each group. In each case, $2 \mu \mathrm{g}$ of nuclear extract were incubated with ${ }^{32} \mathrm{P}$-labeled $\mathrm{\kappa B}$ oligonucleotide. The specificity of CREB binding to the CRE sequence was confirmed by the addition of a 500 -fold excess of unlabeled CRE (Cold CREB) or unlabeled heterologous $\kappa \mathrm{B}$ oligonucleotide (Cold $N F-\kappa B$ ). Pretreatment with propranolol reduced constitutive (compare Control and Propranolol) and hemorrhageinduced CREB activation (Hemorrhage and Hem. propranolol). One representative experiment is shown, one additional experiment with another set of animals gave comparable results.

untreated, hemorrhaged mice (Fig. 7, compare Hem. propranolol and Hemorrhage). Treatment of unhemorrhaged animals with propranolol also increased basal activation of $\mathrm{NF}-\mathrm{\kappa}$ in lung cells (Fig. 7, Propranolol).

The hemorrhage-induced increase in phospho-CREB was ablated by $\beta$-adrenergic blockade with propranolol (Fig. 8, compare Hem. propranolol and Hemorrhage). Treatment with propranolol also decreased constitutive activation of CREB in unhemorrhaged mice (Fig. 8, compare Propranolol and Control).

\section{Discussion}

The present experiments demonstrate that activation of NF-кB as well as the enhanced expression of the cytokines IL-1 $\beta$, TNF- $\alpha$, and TGF- $\beta 1$ in pulmonary cell populations during the first hour after hemorrhage is prevented by $\alpha$-adrenergic blockade. These findings suggest that activation of NF- B through an $\alpha$-adrenergic pathway is a mechanism by which blood loss produces increased immunoregulatory cytokine expression in the lungs.

While the present experiments show that $\alpha$-adrenergic blockade prevents NF- $\mathrm{BB}$ activation and increases in IL-1 $\beta$, TNF- $\alpha$, and TGF- $\beta 1$ expression in the lungs during the immediate posthemorrhage period, the effects of $\alpha$-adrenergic block- 
ade on later posthemorrhage events, such as the development of neutrophil-mediated inflammatory lung injury, were not examined. Our previous studies $(8,33)$ found that inhibition of the activity or expression of immunoregulatory cytokines could ameliorate hemorrhage-induced lung injury, suggesting that $\alpha$-adrenergic blockade might prevent acute lung injury in this setting if such therapy was able to suppress proinflammatory cytokine expression throughout the posthemorrhage period. However, it is possible that catecholamines are less important in mediating the increases in immunoregulatory cytokine expression at later time points after blood loss than they are in the immediate posthemorrhage period. In that case, adrenergic blockade would not be expected to affect the subsequent development of acute lung injury. We are presently investigating these issues.

Activation of NF- $\mathrm{B}$ requires phosphorylation, ubiquitination, and proteolytic degradation of the bound inhibitory ІкB protein (55), which then permits translocation to the nucleus of the active p50-p65 heterodimer. $\alpha$-Adrenergic stimulation activates protein kinase $\mathrm{C}(\mathrm{PKC})$ and increases intracellular $\mathrm{Ca}^{2+}$ (56). PKC enhances the initial phosphorylation of IкB leading to the activation of $\mathrm{NF}-\mathrm{kB}(57,58)$. In addition to phosphorylation, dissociation of $\mathrm{I} \kappa \mathrm{B}$ from $\mathrm{NF}-\kappa \mathrm{B}$ requires proteolytic degradation of the $\mathrm{COOH}$-terminal protein destabilizing sequence of IKB (PEST sequence) by calcium-dependent intracellular proteases (59-63) that also may be activated through $\alpha$-adrenergic-induced increases in intracellular $\mathrm{Ca}^{2+}$.

Reactive oxygen species are generated after physiologic insults associated with ischemia-reperfusion such as blood loss (64). We found in previous experiments (22) that xanthine oxidase-derived oxygen radicals contributed both to posthemorrhage NF- $\mathrm{kB}$ activation and to increases in the expression of proinflammatory cytokines in the lungs. Catecholamines, through their degradation to quinones, lead to the formation of superoxide anion radical and hydrogen peroxide $(65,66)$. In addition, during anaerobic conditions such as occur in ischemic tissues catecholamines can release iron from ferritin, and then can react with the released iron and xanthine oxidase to produce reactive hydroxyl radicals (65). Furthermore, NADPH oxidase-dependent hydroxyl radical production is increased in activated macrophages and polymorphonuclear leukocytes by PKC activation and elevation in intracellular $\mathrm{Ca}^{2+}$ (67-69). Both of these conditions occur after $\alpha$-adrenergic stimulation (56). Because the activation of $\mathrm{NF}-\kappa \mathrm{B}$ by reactive oxygen species requires high levels of intracellular $\mathrm{Ca}^{2+}(70,71)$, it is therefore possible that hemorrhage-induced $\alpha$-adrenergic stimulation may enhance $\mathrm{NF}-\kappa \mathrm{B}$ activation and proinflammatory cytokine expression in the lung through two mechanisms; i.e., either by directly increasing the production of reactive oxygen species or through activating PKC and increasing intracellular $\mathrm{Ca}^{2+}$.

In the present experiments, $\beta$-adrenergic blockade increased basal and hemorrhage-induced NF- $\mathrm{KB}$ activation when compared with the untreated animals. These findings, coupled with the enhancing effect of $\beta$-adrenergic blockade on hemorrhage-induced proinflammatory cytokine expression, reinforce the central role that NF-кB occupies in affecting immunoregulatory mechanisms in the lung after blood loss. Our results also suggest that $\beta$-adrenergic stimulation may act to downregulate the initial increase in lung proinflammatory cytokine expression produced by hemorrhage through attenuating NF-кB activation.
The decrease in NF- $\mathrm{BB}$ activation by $\beta$-adrenergic receptor stimulation could involve cAMP-regulated changes in PKA activation since $\beta$-adrenergic stimulation increases intracellular levels of cyclic AMP that subsequently activate PKA (72). Despite the fact that PKA can activate NF- $\mathrm{B}$ in cytosolic extracts $(57,58)$, there is strong evidence that cAMP acts via PKA as an inhibitor of NF- $\mathrm{B}$ activation in the intact cell (73, 74). For example, in EL4.E1 cells, NF-кB activation is inhibited by increased levels of cAMP, but this downregulatory effect of cAMP on NF-кB activation can be blocked by introduction of a dominant negative mutant subunit of PKA into the cells (73). Additionally, mutations preventing NF- $\kappa \mathrm{B}$ binding to the IL-2 promoter lead to the loss of PKA-mediated reduction of IL-2 promoter activity by forskolin (74). The inhibitory effect of increased cAMP via PKA may also involve retarded degradation of $\mathrm{I}_{\mathrm{B}} \mathrm{B}$, as well as decreased synthesis of $\mathrm{NF}-\kappa \mathrm{B}$ subunits $(73,74)$.

We found that even though $\alpha$-adrenergic blockade was associated with a reduction of CREB phosphorylation in lung mononuclear cells and a decrease in proinflammatory cytokine expression, an even greater reduction in CREB phosphorylation after $\beta$ blockade was not associated with reduction in lung proinflammatory cytokine expression. Given these findings, it is clear that CREB phosphorylation is not the primary activation event producing alterations in lung proinflammatory cytokine expression after hemorrhage. Our present results do not eliminate a contributory role for CREB in affecting pulmonary cytokine expression after hemorrhage, but rather demonstrate that activation of $\mathrm{NF}-\mathrm{kB}$ is a dominant event in this setting.

\section{Acknowledgments}

This work was supported in part by NIH grant HL-50284 and a gift from Barbara Pfifferling and Marc Arnold. Y. Le Tulzo was a recipient of the Yearly Award to Young Investigators from the European Society of Intensive Care Medicine, a Research Award from N.A.T.O., and was supported by grants from Société de Réanimation de Langue Française, Institut Henri Beaufour, and Institut SmithKline-Beecham.

\section{References}

1. Repine, J.E. 1992. Scientific perspectives on the adult respiratory distress syndrome. Lancet. 339:466-469.

2. Sauaia, A., F.A. Moore, E.E. Moore, J.B. Haenel, R.A. Read, and D.C. Lezotte. 1994. Early predictors of postinjury multiple organ failure. Arch. Surg. 129:39-45.

3. Hyers, T.M. 1993. Prediction of survival and mortality in patients with adult respiratory distress syndrome. New Horiz. 1:466-470.

4. Shenkar, R., and E. Abraham. 1993. Effects of hemorrhage on cytokine gene transcription. Lymphokine Cytokine Res. 12:237-247.

5. Donnelly, S.C., R.M. Strieter, S.L. Kunkel, A. Walz, C.R. Robertson, D.C. Carter, I.S. Grant, A.J. Pollok, and C. Haslett. 1993. Interleukin-8 and the development of adult respiratory distress syndrome in at-risk patient groups. Lancet. 341:643-647.

6. Suter, P.M., S. Suter, E. Girardin, P. Roux-Lombard, G.E. Grau, and J.M. Dayer. 1992. High bronchoalveolar levels of tumor necrosis factor and its inhibitors, interleukin-1, interferon, and elastase in patients with adult respiratory distress syndrome after trauma, shock, or sepsis. Am. Rev. Respir. Dis. 145: 1016-1022.

7. Jacobs, R.F., D.R. Tabor, A.W. Burks, and D.G. Campbell. 1989. Elevated interleukin-1 release by human alveolar macrophages during the adult respiratory distress syndrome. Am. Rev. Respir. Dis. 140:1686-1692.

8. Shenkar, R., W.F. Coulson, and E. Abraham. 1994. Anti-transforming growth factor monoclonal antibodies prevent lung injury in hemorrhaged mice. Am. J. Respir. Cell Mol. Biol. 11:351-357.

9. Nakai, M., M. Kawamura, T. Kunieda, Y. Yamane, Y. Umeda, and M. Inada. 1991. Intrapulmonary bronchial circulation during hemorrhage. Heart 
Vessels. 6:90-95.

10. Moss, G., and A.A. Stein. 1976. The centrineurogenic etiology of the respiratory distress syndrome: protection by unilateral chronic pulmonary denervation in hemorrhagic shock. J. Trauma. 16:361-364.

11. Van Gool, J., H. Van Vugt, M. Helle, and L.A. Aarden. 1990. The relation among stress, adrenaline, interleukin- 6 and acute phase proteins in the rat. Clin. Immunol. Immunopath. 57:200-210.

12. Sanders, V.M., and A.E. Munson. 1985. Role of alpha-adrenoreceptor activation in modulating the murine primary antibody response in vitro. $J$. Pharmacol. Exp. Ther. 232:395-400.

13. Bartik, M.M., W.M. Brooks, and T.L. Roszman. 1993. Modulation of T cell proliferation by the stimulation of the $\beta$-adrenergic receptor: lack of correlation between inhibition of $\mathrm{T}$ cell proliferation and cAMP accumulation. Cell Immunol. 148:408-421.

14. Shen, H.M., J.L. Kennedy, and D.W. Ou. 1994. Adrenergic receptors regulate macrophage secretion. Int. J. Immunopharmacol. 16:905-910.

15. Hasko, G., I.J. Elenkov, V. Kvetan, and E.S. Visi. 1995. Differential effect of selective block of $\alpha_{2}$-adrenoreceptors on plasma levels of tumor necrosis factor- $\alpha$, interleukin- 6 and corticosterone induced by bacterial lipopolysaccharide in mice. J. Endocrinol. 144:457-462.

16. Spengler, R.N., R.M. Allen, D.G. Remick, R.M. Strieter, and S.L. Kunkel. 1990. Stimulation of $\alpha$-adrenergic receptor augments the production of macrophage-derived tumor necrosis factor. J. Immunol. 145:1430-1434.

17. Spengler, R.N., S.W. Chensue, D.A. Giachero, N. Blenk, and S.L. Kunkel. 1994. Endogenous norepinephrine regulates tumor necrosis factor- $\alpha$ production from macrophages in vitro. J. Immunol. 152:3024-3031.

18. Severn, A., N.T Rapson, C.A. Hunter, and F.Y. Liew. 1992. Regulation of tumor necrosis factor production by adrenaline and $\beta$-adrenergic agonists. $J$. Immunol. 148:3441-3445.

19. Tannenbaum, C.S., and T.A. Hamilton. 1989. Lipopolysaccharide-induced gene expression in murine peritoneal macrophages is selectively suppressed by agents that elevate intracellular cAMP. J. Immunol. 142:1274-1280.

20. Koff, W.C., A.V. Fann, M.A. Dunegan, and L.B. Lachman. 1986. Catecholamine-induced suppression of interleukin-1 production. Lymphokine Res. 5:239-245.

21. Van der Poll, T., J. Jansen, E. Endert, H.P. Sauerwein, and S.H.J. Van Deventer. 1994. Noradrenaline inhibits lipopolysaccharide induced tumor necrosis factor and interleukin-6 production in human whole blood. Infect. Immun. 62:2046-2050.

22. Shenkar, R., M.D. Schwartz, L.S. Terada, J.E. Repine, J. McCord, and E. Abraham. 1996. Hemorrhage activates NF-кB in murine lung mononuclear cells in vivo. Am. J. Physiol. 270:L729-L735.

23. Shenkar, R., and E. Abraham. 1996. Plasma from hemorrhaged mice activates CREB and increases cytokine expression in lung mononuclear cells through a xanthine oxidase dependent mechanism. Am J. Respir. Cell Mol. Biol. 14:198-206.

24. Hiscott, J., J. Marois, J. Garoufalis, M. D'Addario, A. Roulston, I. Kwan, N. Pepin, J. Lacoste, H. Nguyen, G. Bensi, and M. Fenton. 1993. Characterization of a functional NF-кB site in the human interleukin-1 $\beta$ promoter: evidence for a positive autoregulatory loop. Mol. Cell. Biol. 13:6231-6240.

25. Cogswell, J.P., M.M. Godlevski, G.B. Wisely, W.C. Clay, L.M. Leesnitzer, J.P. Way, and J.G. Gray. 1994. NF-kappa B regulates IL-1ß transcription through a consensus NF-kappa B binding site and a non consensus CRE-like site. J. Immunol. 153:712-723.

26. Lorenz, J.J., P.J. Furdon, J.D. Taylor, M.W. Verghese, G. Chandra, T.A. Kost, S.A. Haneline, L.A. Ronner, and J.G. Gray. 1995. A cyclic adenosine 3' $5^{\prime}$ monophosphate signal is required for the induction of IL- $1 \beta$ by TNF- $\alpha$ in human monocytes. J. Immunol. 155:836-844.

27. Newell, C.L., A.B. Deisseroth, and G. Lopez-Berestein. 1994. Interaction of nuclear proteins with an AP-1/CRE like promoter sequence in the human TNF- $\alpha$ gene. J. Leukocyte Biol. 56:27-35.

28. Collart, M.A., P. Baeuerle, and P. Vassili. 1990. Regulation of tumor necrosis alpha transcription in macrophages: involvement of four $\mathrm{\kappa B}$-like motifs and of constitutive and inducible forms of NF-кB. Mol. Cell. Biol. 10:14981506.

29. Asiedu, C.K., L. Scotto, R.K. Assoian, and M. Ehrich. 1994. Binding of AP-1/CREB proteins and of MDBP to contiguous sites downstream of the human TGF- $\beta 1$ gene. Biochim. Biophys. Acta. 1219:55-63.

30. Schwartz, M.D., J.E. Repine, and E. Abraham. 1995. Xanthine oxidasederived oxygen radicals increase lung cytokine gene expression in mice subjected to hemorrhagic shock. Am. J. Respir. Cell Mol. Biol. 12:434-440.

31. Robinson, A., and E. Abraham. 1992. Effects of hemorrhage on bacterial antigen specific pulmonary plasma cell function. Clin. Exp. Immunol. 88: 124-128.

32. Abraham, E., and A.A. Freitas. 1989. Hemorrhage produces abnormalities in lymphocyte function and lymphokine generation. J. Immunol. 142:899906

33. Abraham, E., S. Bursten, R. Shenkar, J. Allbee, R. Tuder, P. Weedson, D.M. Guidot, G. Rice, J.W. Singer, and J.E. Repine. 1995. Phosphatidic acid signaling mediates lung cytokine expression and lung inflammatory injury after hemorrhage in mice. J. Exp. Med. 181:569-575.

34. Robinson, A., and E. Abraham. 1991. Effects of hemorrhage and resus- citation on bacterial antigen-specific pulmonary plasma cell function. Crit. Care Med. 19:1285-1293.

35. Ramaswamy, S., D. Srinivasan, and J.S. Bapna. 1992. Inhibition of tetrahydroisoxazolo-pyridin-3-ol and muscimol and its mechanism on gastrointestinal transit in mice. Eur. J. Pharm. 220:147-149.

36. Karlsson, S., A.J. Scheurink, A.B. Steffens, and B. Ahren. 1994. Involvement of capsaicin-sensitive nerves in regulation of insulin secretion and glucose tolerance in conscious mice. Am. J. Physiol. 267:R1071-R1077.

37. Heilig, M., M. Irwin, I. Grewal, and E. Sercarz. 1993. Sympathetic regulation of T-helper cell function. Brain Behav. Immun. 7:154-163.

38. Moursi, M.N., H.G. Beebe, L.M. Messina, T.H. Welling, and J.C. Stanley. 1995. Inhibition of aortic aneurysm development in blotchy mice by beta adrenergic blockade independent of altered lysyl oxidase activity. J. Vasc. Surg. 21:792-799.

39. Elenkov, I.J., G. Hasko, K.J. Kovacs, and E.S. Vizi. 1995. Modulation of lipopolysaccharide-induced tumor necrosis factor alpha production by selective alpha- and beta-adrenergic drugs in mice. J. Neuroimmunol. 61:123-131.

40. Gorman, A.L., and A.J. Dunn. 1993. Beta-adrenergic receptors are involved in stress-related behavioral changes. Pharmacol. Biochem. Behav. 45:1-7.

41. Abraham, E., A.A. Freitas, and A.A. Coutinho. 1990. Purification and characterization of intraparenchymal lung lymphocytes. J. Immunol. 144:21172122.

42. Shenkar, R., W.F. Coulson, and E. Abraham. 1994. Hemorrhage and resuscitation induce alteration in cytokine expression and the development of acute lung injury. Am. J. Respir. Cell Mol. Biol. 10:290-297.

43. Chomczynski, P., and N. Sacchi. 1987. Single step method of RNA isolation by acid guanidium thiocyanate-phenol chloroform extraction. Anal. Biochem. 162:156-161.

44. Kawasaki, E.S. 1991. Amplification of RNA. In: PCR Protocols: A Guide to Methods and Applications. M.A. Innis, D.H. Gelfand, J.J. Sninsky, and T.J. White, editors. Academic Press, New York. 21-27.

45. Siebert, P.D., and J.W. Larrick. 1993. PCR MIMICS: competitive DNA fragments for use as internal standards in quantitative PCR. Biotechniques. 14 244-249.

46. Passon, P.G., and J.D. Peuler. 1973. A simplified radiometric assay for plasma norepinephrine and epinephrine. Anal. Biochem. 51:618-631.

47. Durrett, L.R., and M.G. Ziegler. 1980. A sensitive radioenzymatic assay for catechol drugs. J. Neurosci. Res. 5:587-598.

48. Fantuzzi, G., H. Zheng, R. Faggioni, F. Benigni, P. Ghezzi, J.D. Sipe, A.R. Shaw, and C.A. Dinarello. 1996. Effect of endotoxemia on IL-1ß-deficient mice. J. Immunol. 157:291-296.

49. Qian, J., V. Bours, J. Manischewitz, R. Blackburn, U. Siebenlist, and H Golding. 1994. Chemically selected subclones of the CEM cell line demonstrate resistance to HIV-1 infection resulting from a selective loss of NF-кB DNA binding protein. J. Immunol. 152:4183-4191.

50. Dignam, J.D., P.L. Martin, B.S. Shatry, and R.F. Roeder. 1983. Eukariotic gene transcription with purified components. Methods Enzymol. 101:582598.

51. Zabel, U., R. Scherck, and P.A. Baeuerle. 1991. DNA binding of purified transcription factor NF-кB: affinity, specificity, $\mathrm{Zn}^{2+}$ dependence and differential half-site recognition. J. Biol. Chem. 266:252-260.

52. Roesler, W.J., G.R. Vandenbark, and R.W. Hanson. 1988. Cyclic AMP and the induction of eukariotic gene transcription. J. Biol. Chem. 263:90639066

53. Lalli, E., and P. Sassone-Conti. 1994. Signal transduction and gene regulation: the nuclear response to cAMP. J. Biol. Chem. 269:17359-17362.

54. Shenkar, R., and E. Abraham. 1996. Hemorrhage activates CREB and NF-кB in lung lymphocytes in vivo. FASEB (Fed. Am. Soc. Exp. Biol.) J. 10 A1333. (Abstr.)

55. Baeuerle, P.A., and T. Henkel. 1994. Function and activation of NF-кB in the immune system. Annu. Rev. Immunol. 12:141-179.

56. Exton, J.H. 1985. Mechanisms involved in $\alpha$-adrenergic phenomena Am. J. Physiol. 248:E633-E647.

57. Ghosh, S., and D. Baltimore. 1990. Activation in vitro of NF-kB by phosphorylation of its inhibitor IкB. Nature (Lond.). 344:678-682.

58. Shirakawa, F., and S.B. Mizel. 1989. In vitro activation and nuclear translocation of NF-кB catalyzed by cyclic AMP-dependent protein kinase and protein kinase C. Mol. Cell. Biol. 9:2424-2430.

59. Finco, T., A. Beg, and A. Baldwin. 1994. Inducible phosphorylation of Iк $\mathrm{B} \alpha$ is not sufficient for its dissociation from NF-кB and is inhibited by protease inhibitors. Proc. Natl. Acad. Sci. USA. 91:884-888.

60. Sen, C.K., S. Roy, and L. Packer. 1996. Involvement of intracellular $\mathrm{Ca}^{2+}$ in oxidant-induced NF-кB activation. FEBS Lett. 385:58-62.

61. Frantz, B., E. Nordby, G. Bren, N. Steffan, C. Paya, R. Kincaid, M. Tocci, S. O'Keefe, and E. O'Neill. 1994. Calcineurin acts in synergy with PMA to inactivate IкB/MAD-3, an inhibitor of NF-кB. EMBO (Eur. Mol. Biol Or gan.) J. 13:861-870.

62. Watt, F., and P.L. Molloy. 1993. Specific cleavage of transcription factors by the thiol protease, m-calpain. Nucleic Acids Res. 21:5092-5100.

63. Liu, Z., M. Kunimatsu, J.P. Yang, Y. Ozaki, M. Sasaki, and T. Okamoto. 1996. Proteolytic processing of nuclear factor $\kappa \mathrm{B}$ by calpain in vitro. FEBS Lett. 385:109-113. 
64. Tan, S., Y. Yokoyama, E. Dickens, T.G. Cash, A. Freeman, and D.A. Parks. 1993. Xanthine oxidase activity in the circulation of rats following hemorrhagic shock. Free Radical Biol. Med. 15:407-414.

65. Allen, D.R., G.L. Wallis, and P.B. McCay. 1994. Catechol adrenergic agents enhance hydroxyl radical generation in xanthine oxidase systems containing ferritin: implications for ischemia/reperfusion. Arch. Biochem. Biophys. 315:235-243.

66. Powis, G., and P.G. Appel. 1979. Relationship of the single-electron reduction potential of quinones to their reduction by flavoproteins. Biochem. Pharmacol. 29:2567-2572.

67. Johnston, P.A., D.O. Adams, and T.A. Hamilton. 1986. Regulation of respiratory burst in murine peritoneal macrophages: differential sensitivity to phorbol diesters by macrophages in different states of functional activation. Cell. Immunol. 100:400-410.

68. Mitsuyama, T., T. Tanaka, K. Hidaka, M. Abe, and N. Hara. 1995. Inhibition by erythromycin of superoxide anion production by human polymorphonuclear leukocytes through the action of cyclic AMP-dependent protein kinase. Respiration. 62:269-273.

69. Mitsuyama, T., K. Takeshige, T. Furuno, T. Tanaka, K. Hidaka, M. Abe, and N. Hara. 1995. An inhibitor of cyclic AMP-dependent protein kinase enhances the superoxide production of human neutrophils stimulated by $N$-formyl-methionyl-leucyl-phenylalanine. Mol. Cell. Biochem. 145:19-24.

70. Schreck, R., P. Rieber, and P.A. Baeuerle. 1991. Reactive oxygen intermediates as apparently widely used messengers in the activation of the NF-kB transcription factor and HIV-1. EMBO (Eur. Mol. Biol. Organ.) J. 10:22472258 .

71. Satriano, J., and D. Schlondorff. 1994. Activation and attenuation of transcription factor NF- $\mathrm{BB}$ in mouse glomerular mesangial cells in response to tumor necrosis factor- $\alpha$, immunoglobulin $G$, and adenosine $3^{\prime}: 5^{\prime}$-cyclic monophosphate. J. Clin. Invest. 94:1629-1636.

72. Barnes, P.J. 1995. Beta-adrenergic receptors and their regulation. Am. J. Respir. Crit. Care Med. 152:838-860.

73. Chen, D., and E.V. Rothenberg. 1994. Interleukin-2 transcription factors as molecular targets of cAMP inhibition: delayed inhibition kinetics and combinatorial transcription roles. J. Exp. Med. 179:931-942.

74. Neumann, M., T. Grieshammer, S. Chuvpilo, B. Kneitz, M. Lohoff, A. Schimpl, B.R. Franza, Jr., and E. Serfling. 1995. RelA/p65 is a molecular target for the immunosuppressive action of protein kinase A. EMBO (Eur. Mol. Biol. Organ.) J. 14:1991-2004. 